\title{
GAÁL BOTOND
}

\section{HATVANI ISTVÁN, A POLIHISZTOR PROFESSZOR*}

\begin{abstract}
ISTVÁn HATVANi, the POLYHISTOR PROFESSOR. István Hatvani interpreted his professorship as profession devoted to cultivation and instruction of sciences. Besides being a determined theologian of the Reformed Church, he also owned profund knowledge in all disciplines of natural sciences of his age. As well, he was aware of the relationship between these two fields of sciences and philosophy. According to his considerations, the Newtonian view of nature was acceptable, which explains him discarding the, logic-deductive based science concept' of Christian Wolff. His passion to work, as well as to his marriage was deeply influenced by his Christian faith.
\end{abstract}

Hatvani István szellemi örökségének jelentőségét akkor látjuk helyesen, ha őt európai mértékkel mérjük. Természetesen figyelünk a hazai történelmi folyamatokra, de amikor róla beszélünk, „vigyázó tekintetünkkel” folyamatosan a nyugati tudományos életet pásztázzuk. Három ilyen szellemi természetű folyamatban igyekszünk föllelni Hatvani jelentőségét.

\section{$I$.}

Először egy olyan történeti összefüggést említünk, amelyet e szerző már többször és több helyen hangsúlyozott. ${ }^{1}$ A 16 . században, amikor Mohács után hazánkat három részre tépte a történelem vihara, az egyetemképes fiatalok külföldjárása, ha csökkent számban is, fennmaradt. Ezek a peregrinus diákok a latin nyelv ismerete alapján betekintést nyertek a nyugati pezsgő szellemi életbe, megismerték a tudományos és társadalmi fejlődés eredményeit, hasznait. Látták a technikai fejlődést, melyet elsősorban a hajóépítés és az impozáns templomok, középületek létrehozása révén csodáltak meg. Az egyetemek sokasága és a tudományos diszciplínák változatossága nagyszerủ kínálatot jelentett számukra, egyben mintát, modellt is. Hazajőve azonban látták a nyomorúságos helyzetet. Sem egyetem nem volt idehaza, sem kellő számú iskola, így a nép műveltsége rendkívül alacsony szinten lehetett, a technikai színvonal pedig kétségbe-

* Előadásként elhangzott Hatvani István születésének 300. évfordulóján a DAB-ban rendezett emlékülésen 2018. november 21-én.

${ }^{1}$ Vö. GaÁl Botond, A reformáció lényege: Ujjkori modellváltás a keresztyén gondolkodás történetében. (Debrecen: Debrecen-Nagytemplomi Református Egyházközség Karakter 1517 Könyvesbolt és Kávézó, 2017). 
ejtő képet mutatott. A külföldet járt diákok azonban a nyugati egyetemekről komoly tudással, s az ottani fejlődő polgári társadalom új szemléletével, annak technikai fejlettségére vonatkozó ismereteivel jöttek haza. Itthon dönteniük kellett, méghozzá egy olyan történelmi helyzetben, amikor hazájuk is odaveszni látszott. Úgy látták, hogy a körülmények ellenére nincs más kiút, minthogy iskolákat kell alapítani. A tudás révén a műveltségi szint növekedésétől remélték a szellemi-társadalmi-technikai-gazdasági emelkedést. Tulajdonképpen egy nemzetépítő programot hirdettek meg, amikor hallgattak Méliusz Juhász Péter programkiáltására: „Csináljatok a templomokból iskolákat!”2 Száz évvel később Mikolai Hegedűs János már ezt mondhatta: „Ihol az Úr az ö szolgái által megparancsolta a Magyar scholák épittetését, s hogy megfogyatkozott a szegénység!"3

Indultak tehát a semmiből és hallatlan akarattal fölhozták hazánkat sok területen európai szintre. Ez már kezdett látszani a 17. század vége tájban, majd nagy lendületet kapott Maróthi György sokrétűségével, de főként akkor következett be, amikor Debrecenben Hatvani István tanított professzorként. Pintér Ákos matematika professzor az Eulerhez hasonló tehetségűek sorában helyezte őt el, azzal a megjegyzéssel, hogy ha nyugaton marad, valószínűleg a tudománytörténet legnagyobbjai között emlegetnék a nevét. $^{4}$

II.

Engem mindig is foglalkoztatott a felsőoktatás kérdése, mert látva az európai tudományos fejlődés történetét, a középkor vége tájban, a 11. és 13. század közti időszakban alapított egyetemek, ún. universitasok hallatlan lendületet adtak az európai fejlődésnek. Számomra úgy tünik, hogy az addig párhuzamosan fejlődő kínai és európai tudományos életben az 1400-as évektől egyszer csak hirtelen változás következett be az európai kultúra javára, és ez így emelkedett folytonosan a 20. századig. Ebben a legjelentősebb érdeme az egyetemeknek van. A 16. századtól ez már nyilvánvalóvá vált. Nálunk viszont az oszmán hódítás lehetetlenné tette ilyen intézmények létrehozását. Arról nem is jó beszélni, milyen pusztítást és visszamaradottságot jelentett a Mátyás király idejében még virágzott magyar szellemi élethez képest. Mármost a hazatérő reformátorok ezért is döntöttek az iskolák létrehívásáról, s így jöttek létre a nagy kollégiumok, amelyek iskolacentrumként működve hamar felsőfokú intézménnyé váltak. Amikor hat

${ }^{2}$ Szabó Károly, Régi Magyar Könyvtár: Az 1531-1711. megjelent magyar nyomtatványok könyvészeti kézikönyve I., (Budapest: M. Tud. Akadémia, 1879), 55.

3 Eredeti közlési helye Alexander Grosse katekizmusának, „Az mennyei igazságnak tüzes oszlopa ... ” címmel Utrechtben kiadott magyar fordítása fordítói utószava. Régi Magyar Nyomtatványok (Budapest: Akadémiai Kiadó, 2000), nr. 2249. Köszönöm Baráth Bélának, hogy erre az idézetre és az idézett helyre fölhívta a figyelmemet.

${ }^{4}$ Pintér Ákos matematikus professzor 2008-ban a Kollégium Oratoriumában úgy jellemezte Hatvani István tudós képességét: „Ha Nyugaton maradt volna, ma valószinüleg olyanok között emlitenék a nevét, mint Euler vagy a Bernoulliak." 
évvel ezelőtt megírtam a saját tanszékem történetét, kiderült, hogy az én tanszékem a legrégibb, egyfolytában működő tanszék a magyarországi felsőfokú oktatásban. Bár a Kollégium müködését 1538-tól számítjuk, de a tanszékemről csak annyit tudunk, hogy az 1567-ben keltezett jegyzőkönyvi adatok szerint olyan tárgyakat kellett tanítani, amelyeket csak felsőfokon oktattak. ${ }^{5} \mathrm{Az}$ én tanszékem a rendszeres teológia nevet viselte, kezdetben a teológia és a filozófia együtt volt, a dogmatika elnevezést csak 1659 után kezdték használni. Igyekszem azonban megjegyezni, hogy 1704 előtt, amikor a tantárgyak még nem voltak rögzítve a tanszékekhez, hívták a tanszékemet „hit és mértan" tanszéknek is. ${ }^{6}$

Hogy mindezt miért bocsátottuk előre, és mi köze van ezeknek Hatvani Istvánhoz, most szeretnénk láttatni. Aki a Debreceni Kollégium tudománytörténeti múltjába szakszemmel beletekint, annak eléggé egyértelműen rajzolódik ki, hogy ez a nagytekintélyü iskolaközpont négyszáznyolcvan éves története során háromszor is egyetemmé válhatott volna. Azért, mert bizonyos időszakokban olyan képességü és tudású tanártársak dolgoztak együtt, akik valóban egyetemi színvonalat képviseltek az akkori európai felsőoktatás mércéjével mérve. Elöször az 1660-as és 1670-es évekre gondolhatunk, amikor Komáromi Csipkés György, Martonfalvi Tóth György, Lisznyai Kovács Pál, Szilágyi Tönkő Márton tanítottak Debrecenben. Szilágyi Tönkő Márton vezette be az akkor modernnek számító kartéziánus szemléletet valamennyi szaktárgyban. A második ilyen „erős korszak” volt a 18. század közepe és második fele, amikor a Kollégium ismét egyetemmé válhatott volna, mert a Maróthi György által megindított felfelé ívelő pályán együtt dolgozhattak Piskárkosi Szilágyi Sámuel, Szathmári Paksi István, Hatvani István és Sinai Miklós. Ezek mind hatalmas képességü professzorok voltak. A városban élt és dolgozott ekkor Weszprémi István is. Közülük is kiemelkedik Hatvani, akinek személye meghatározta az egész Kollégium tekintélyét. Harmadik ilyen kedvező helyzet a 19. század 20-as, 30-as és 40-es éveiben alakult ki, ugyanis ekkor tanítottak itt Budai Ézsaiás, Kerekes Ferenc, Sárvári Pál, Péczely József, Lugossy József, Csécsi Nagy Imre, Vecsei József, Szűcs István, akiket mind tagjai sorába választott a Magyar Tudós Társaság, illetve a Magyar Tudományos Akadémia. Kár, hogy ez a helyzet nem fordította jobbra a Kollégium sorsát. Az utókor számára szinte elszalasztott alkalomnak tünik, de az akkori magyarországi helyzetet ismerve nem csodálkozhatunk azon, hogy a bécsi udvarhoz hű emberek valósággal rettegtek egy feltörekvő protestáns szellemi központ

\footnotetext{
${ }^{5}$ Vö. GaÁL Botond, Kis tanszékböl nagy egyetem. (Debrecen: DRHE - Hatvani István Teológiai Kutatóközpont, 2012), 24.

${ }^{6}$ Vö. Zsigmond Ferenc, A Debreceni Református Kollégium története 1538(?)-1938. (Debrecen: Debrecen Szabad Királyi Város és a Tiszántúli Református Egyházkerület Könyvnyomda Vállalata, 1937). 88. Ez kissé derüsen hangzik a 20. és a 21. századi ember számára, de végül is a maga teljességében az a tény, hogy a dogmatika professzora "hit és mértan" tanári címet viseljen, csak 1987-től valósult meg e tanulmány szerzőjének személyében.
} 
veszélyes létrejöttétől. ${ }^{7} \mathrm{Mi}$ most ebbe a majdnem kétszázados történelmi folyamatba ágyazódva gondolkodunk, és kiszemeljük belőle Hatvani Istvánt, aki a Debreceni Kollégium történetében a legnagyobb polihisztorként emelkedik a magasba.

\section{III.}

Hatvani kapcsán értjük meg jobban, miként kapcsolódik a 18. századi cívis város az európai szellemi élet fóáramához. Igen bonyolult időszakról van szó. Ekkor vannak feljövőben a természettudományok, s ez határozza meg a Kollégium munkáját is. Ezekben az évtizedekben lépnek színre a már említett nagy tanárok, Maróthi György, Piszkárkosi Szilágyi Sámuel, Sinai Miklós és Hatvani István. 1752-től itt tanít Varjas János, a neves hebraista teológus, 1760-tól pedig Szathmári Paksi Istvánt választották tanárnak a történelem és rendszeres teológiai tanszékre. A városban ekkor müködik Weszprémi István, a híres orvos. Valósággal ez egy erős professzori kar! A teológiai tanszékek tanárai viszont, és az egyházi vezetők is, szinte a háttérből figyelik a fejleményeket. A befolyásos filozófiai áramlatokat ugyanis nem a teológusok, hanem a természettudósok teszik félre. A Szilágyi Tönkő Márton által évtizedekkel korábban bevezetett kartéziánus tudományművelés helyett Maróthi György a Christian Wolff-féle logikaideduktív elveket részesíti előnyben. Aztán jön Hatvani és Európában elsőként teszi félre Wolff eszméit. Ez azért nagy szó, mert Euler, Németország „matematikai fejedelme” sem mert ellene mondani Wolffnak, a kor "filozófiai pápájának". Hatvani megtette! Határozottan kiállt a Newton által képviselt tapasztalás-kisérletezés-következtetés módszere mellett, ezt tartotta helyesnek.

Hogy az akkori európai közszemléletről képet kapjunk, egy történetet mondunk el, amely ugyancsak kapcsolatban volt a Református Kollégiummal. Maróthi még tanította Hatvanit, és mint kiváló növendékének elmondhatta, mi történt Groningenben 1736-ban. Ezt Hatvani egyik fennmaradt levelében említi meg, miszerint még mindig probléma sokaknak, hogy Kopernikusznak vagy Ptolemaiosznak van-e igaza. Azaz: a Föld körül kering-e a világ vagy a Nap körül? Itt látjuk igazán a 18. századi európai helyzetet. Majdnem kétszáz évvel vagyunk Kopernikusz után, Newton sem él már, és Groningenben még ekkor is vitatják a kérdést, mert Descartes szerint a Föld áll, sőt korong alakú. Hatvaninak ezt a levelét az 1960-as évek elején találta meg Tóth Béla tanárunk, aki elment Groningenbe és megkereste, sőt meg is találta Maróthi György ott hagyott 13 oldalnyi írását az egyetemi levéltárban. Mi is volt ez? Akkor Hollandiában

\footnotetext{
${ }^{7}$ Az államtanácsi ülésen és a magyar országgyủlésben, a 19. század első évtizedeiben arról folyt heves vita, hogy a német vagy a magyar nyelv legyen a hivatalos nyelv hazánkban. A hozzászólók felszólalásából tűnik ki, miként viseltettek egyesek a magyar kálvinistákkal szemben. Félelmetes és megdöbbentő! Vö. GAál Botond, „Kálvini vonások a magyarok lelki arcán”, in Kálvin ébresztése. (Debrecen: DRHE Hatvani István Teológiai Kutatóközpont, 2010), 147-148.
} 
az volt a szokás, hogy ha egy professzor állított valamit, azt mint a saját tudományos tételeit egy fiatalabb tudósjelölttel védette meg nyilvánosan, méghozzá a saját elnöklete alatt. Maga a groningeni egyetemi atmoszféra is rendkívüli lehetett. Hollandiában ekkor két egyházi tábor volt, az egyik ellenezte Kopernikusz tanait, a másik támogatta. Mármost Gerdes professzor a kopernikuszi tanok mellett volt és ezt illett nyilvánosan is megvédeni. Ö egyik legtehetségesebb tanítványát választotta ki tételeinek megvédésére, s ez nem volt más, mint a 21 éves debreceni Maróthi György. Nagy tömeg gyűlt össze az egyetem auditoriumában, amikor Maróthi a rangos sokaság előtt meggyőzően kiállt a kopernikuszi gondolatok igazsága mellett, és ezt csillagászati érveléssel tette. Igazából Maróthi érvelése tudományos, önálló gondolkodásra vall és elválasztja a csillagászati kérdéseket a teológiai érvelésektől. Maróthi írása ezért tudománytörténeti szempontból is jelentős. Ugyanis még a kopernikuszi csillagászati modellen is túllép és eljut a newtoni szemléletig, sőt Groningenben egyenesen a newtoni fizika alapján érvel a geocentrikus elmélet ellen a gravitációs gyorsuló mozgás alapján. ${ }^{8}$ Ezen a vitán szóba jött Ticho de Brahe geosztatikus elgondolása is, de Maróthi ezt a modellt is helytelenítette. Akkor és ott az ő érvelése nagyon nagy siker és nevezetes esemény volt, ott Groningenben ugyanis eldőlt a vita Kopernikusz javára. Európa akkor még itt tartott.

Igazából Hatvani Istvánt már elég jól bemutattuk azzal, hogy elhelyeztük őt a saját korában mind a hazai, mind pedig az európai szellemi környezetben. Most tényleges munkásságáról szeretnénk szólni írásai alapján. Előbb azonban nagyon röviden bemutatjuk életútját.

\section{Életrajzi mozzanatok}

Születésének éppen ma van 300. évfordulója. Rimaszombaton látta meg a napvilágot, ott járt iskolába, a Debreceni Kollégium partikulájába, ahonnan vágyott ide, az anyaiskolába. Nagyon érdekes, hogyan nyert felvételt Debrecenbe. Nem ment simán. Elöször nem volt hely, majd jött a pestisjárvány. Nagy általánosságban mondhatjuk el, hogy az ő személyisége valami titokzatosat rejthetett magában. Maróthi már 14 évesen elérte a felsőfokú szintet, Hatvani elméje viszont csak türelemmel gyűjtötte magába a tudást, és igazából csak 23 éves korában kezdett hozzá a felsőszintű tudományokhoz. Később Arany János esetében tapasztalunk hasonló jelenséget. Hatvani is csendes lélekkel, gyorsan és biztosan haladt fölfelé, így lett a retorikai és logikai osztály köztanítója. Tudása

${ }^{8}$ Vö. То́тн Béla, „Maróthi és a magyar csillagászat”. Múzeumi Kurír 9. sz. (1972): 28. Kissé részletesebb leírás és utalás található GaÁl Botond, $A$ természettudományok oktatása és müvelése a Debreceni Kollégiumban, (Debrecen: DRHE - Hatvani István Teológiai Kutatóközpont, 2012), 107-108. 
egyre nyilvánvalóbbá vált. Saját költségén és Debrecen város kiegészítő adományával 1746 tavaszán Baselbe utazott. Itt aztán tehetsége és képessége robbanásszerűen bontakozott ki. Sorsát okosan rendezte, mint aki bensejében érezte tehetségét és tisztában volt a képességeivel. Még 1746-ban beiratkozott az orvosi fakultásra, miközben teológiát tanult, és 1747-ben már meg is szerezte a lelkészi oklevelét, egy hónappal később pedig a teológiai doktorátust. Mindeközben - elmélyülve az orvostudományokban -, 1748 márciusában már az orvosdoktori értekezését is benyújtotta „De aestimatione morborum cum facie" címmel, azaz a betegségeknek az emberi arcról való felismerése témakörben. Meg is védte. Bámulatos teljesítményét Debrecenből is árgus szemekkel figyelték, és már 1747-ben meghívták a Kollégium tanárává, mégpedig a matematika, a filozófia és a kísérleti fizika tantárgyak tanszékére. Közben a zürichi egyetemre is ellátogatott neves professzorokhoz, és még a svájci tartózkodása idején hozzáfogott a matematika kellően magas szintű elsajátításához. Különösen is Johann és Daniel Bernoulli (hugenotta apa és fia) tudós tanároktól tanult sokat. Még 1748-ban elutazott Hollandiába, ahol az utrechti és leideni egyetemeken gyarapította tudását, elsősorban fizikából és matematikából. Rövid idő alatt hatalmas mennyiségű ismeretanyagot sajátított el. Mindkét egyetem marasztalta, de a felkínált professzori állást nem fogadta el, mert a küldő egyháza és nemzete javát szerette volna szolgálni megszerzett tudásával. Egyik életrajzi töredékében erről így vallott: [...] jobban szerettem gyászos helyzetben levö egyházunkat és a csekély jövedelmü tanári hivatalt hazánkban, mint Hollandia virágzó szabadságát és dúsgazdag tanári fizetését. " Megrakodva könyvekkel és természettudományi kísérleti eszközökkel 1748 karácsonyán ért Debrecenbe, és 1749. január 17-én foglalta el tanári állását a "De matheseos utilitate in theologia ac in physica necessitate” című székfoglalójával. E beszéde ragyogóan tükrözi azt a széleskörü interdiszciplináris tudást, amely annak a kornak a polihisztori eszményvilágához tartozott: $A$ matematika haszna a teológiában és annak szükségessége a fizikában. Ez a székfoglaló lényegében egy európai kitekintésü programbeszéd volt.

A három terület együttes említése is mutatja, amit majd ki is fejtett, hogy őt mélyen foglalkoztatta Isten végtelen hatalmának és szeretetének megértése, s ezt akarta elősegíteni, illetve szemléltetni a hiperbola aszimptotájával, a lánctörtekkel és a végtelen sorokkal. Jól tudta, hogy maguk a nagy reformátorok, Luther, Melanchton és Kálvin mennyire sokra becsülték a matematikát, de akiknél ö is tanult Nyugaton, azok is a protestáns nyitottságot képviselték, ${ }^{10} \mathrm{~s}$ ezért említi a székfoglalójában: „Et tandem quid aliud ipse Deus facit: quam perpetuo geometrei." Azaz, "maga Isten is mi mást tesz, mint folyvást "geometrizál. "" Ez a mondat ráadásul a szelíd, tudós ember ragyogó humorára,

9 Vö. Tóтн Béla: „A Kollégium története a XVIII. században”, in A Debreceni Református Kollégium története, (Budapest: MORE Sajtóosztály, 1988), 101. Tóth Béla az idősb Révész Imre 1871-ben, a Vasárnapi Újságban megjelent cikkére hivatkozik.

${ }^{10}$ Vö. GaÁl Botond, A reformáció lényege: Újkori modellváltás a keresztyén gondolkodás történetében, (Debrecen: Karakter 1517 Könyvesbolt, 2017), 33-35.

11 Vö. Lósy-Schмidt Ede, Hatvani István élete és müvei 1718-1786, (Debrecen: Studium, 1931), 83. A fordítás tőlem [G. B.] A latin szövegben a geometrei szó görög betűkkel van írva. 
derűs lelki világára is vall. Minden bizonnyal ő is látta, hogy a 18. századi Európában a tudományok művelését a reformációt közvetlenül megelőző időkben újból fölfedezett euklideszi axiomatikus tudományművelés módszere hatotta át. Innen származik a more geometrico szemlélet. Ez azt jelentette, hogy bármilyen területet művelünk is, azt csak jól megépített alapokra építhetjük. ${ }^{12}$

Ezt azonban ki kell egészítenünk egy gondolattal. Bár Hatvani még a természettudományokat már csak lazán összefogó filozófia keretein belül tanította a matézist, gyakorlatilag azonban külön tudományágnak tekintette, sőt az egyetlen olyan tudománynak, amelynek az eredményeiben megbízhatunk. Lényegében erről tanúskodik a székfoglalója is. Fő művében, az Introductio-ban 1757-ben pedig ilyen sokra értékeli a matematikát:

„Eszerint tehát a megismerés legvégső foka azt követeli, hogy a filozófus minden létező dolognak meg tudja mérni a mennyiségét. Erre a célra találták fel a filozófusok a matematikát. Mivel pedig a megvizsgálandó dolgokban egyszer azok nagyságát, felszínét, tömegét, különbözőségét, másszor pedig az erőt, a gyorsaságot, a mozgást, az idő múlását kell mérnünk: nyilvánvaló, hogy a fizika, a mechanika, a hidrosztatika, a hidraulika, a földmérés, a kronológia, a csillagászat stb. nem nélkülözheti a matematikai megismerést." ${ }^{\text {13 }}$

Hatvani ismerte a végtelen sorokat, valamint a differenciál- és integrálszámítást. ${ }^{14}$ Ez utóbbit csak értékelte a tudományos gondolkodás fejlődése szempontjából, de tanításáról még szó sem lehetett, nemhogy nálunk, még Európában máshol sem, mivel erre még nem érett meg az idő. Legfeljebb szük tanítványi körben taníthatta ezt a legtehetségesebbeknek. Meg kell azonban jegyeznünk, hogy még közelítőleg sem tudjuk megítélni, mit és milyen mélységig tudott Hatvani a matematika tudományából, csupán azt látjuk, hogy korának minden fontos és új felfedezését ismerte, illetve jelentőségüket felismerte. Ö az első magyar matematikus, aki a valószínűség-számítást a hazai gyakorlatban alkalmazta is, és az alkalmazás területén újat is alkotott. Például a halálozási statisztikában alkalmazta a nagy számok törvényét. ${ }^{15}$ Introductio-jának egy igen tekintélyes fejezete a „De Probabilitate” címet viseli. A tudománytörténészek őt tartják az első politikai aritmetikával és közgazdaságtannal foglalkozó magyar tudósnak. A fizika szemszögéből nézve is sokra kell értékelnünk, hogy Hatvani komolyabb szintű matematikai tudás birtokában volt, és felismerte, hogy e nélkül nem lehet a természet törvényeit megérteni, tehát a szemléltetés vagy kísérletezés sem nyújthat mérvadó támpon-

12 Vö. GAÁL Botond, Zárt világ felnyitása, (Debrecen: DRHE - Hatvani István Teológiai Kutatóközpont, 2007), 35-49.

${ }^{13}$ Hatvani István, Introductio ad principia philosophiae solidoris, conscripta a Stephano Hatvani, (Debrecen: Kállai György szedése, 1757), 55. (Tóth Péter fordítása.)

${ }^{14}$ Vö. M. Zemplén Jolán, A magyarországi fizika története a XVIII. században: A fizika szaktudománnyá válik, (Budapest: Akadémiai Kiadó, 1964), 101.

15 Vö. SzÉnÁssy Barna, A magyarországi matematika története a 20. század elejéig, (Budapest: Akadémiai Kiadó, 1970), 84., 86. és 88., ahol bővebb leírás található Hatvani idevágó munkásságáról. 
tot, ha nem kapcsoljuk össze azokat a mennyiségekre vonatkozó törvényszerüségekkel. Nála már előtűnik a jelenségek kvalitatív vizsgálatához képest az újabb ismeretekre vezető kvantitatív összefüggésekkel dolgozó szemlélet, amely a tudományos fejlödés, elörelépés egyetlen és érvényes módja mindmáig.

\section{A tanitott tárgyak sokfélesége}

Hatvani István bámulatos szellemi képessége az ekkori szűk három éves peregrinus útján bontakozott ki. Figyelmét nem csupán egy területre összpontosította, hanem a korabeli tudományok szinte valamennyi ágát lényegileg fölfogta, megtanulta. Hatvanit népe, nemzete sorsa mélyen aggasztotta, ezért hazajőve hozta magával mindazt a tudományt, amelyet a nyugati világban egyáltalán magába szívhatott. Idehaza a nagy tudású ember szerénységével élte meg a maga szellemi függetlenségét professzorsága alatt. ${ }^{16}$ Hatvani lelkének egyik felével itthon volt, másik felével a nyugati szellemi, tudományos életet kémlelte. ${ }^{17}$ Tudósként eredeti egyéniség volt, igazi polihisztor. Nemcsak átfogó tudása imponáló, hanem munkásságának részletei is megkapó mélységről árulkodnak. Amihez hozzányúlt a tudományban, azt komolyan művelte és tanította. Ismerte korának egész teológiai és természetfilozófiai irodalmát. Különleges tehetsége lehetővé tette számára, hogy a leginkább mérvadó tudósok, személyiségek munkái alapján tájékozódjék az ismeretszerzésben. Teológiájában karakteresen református, de sokat tanult John H. Wincklertől és William Derhamtól; az előbbitől theologia naturalist, az utóbbitól ún. fizikoteológiát. ${ }^{18}$ Egyiket sem követte azonban szolgai módon. A filozófiában Johann Gottlieb Heineccius (Heinecke), a matematika oktatásában Johann Friedrich Weidler műveit használta forrásként. Tudása azonban ezeknél jóval szélesebb volt. Hogy a különböző természettudományi ágak akkori ismeretanyagából mit és mennyit tudott Hatvani, csak becsülni tudjuk ${ }^{19}$ részben az itt-ott fennmaradt tantárgyfelosztásokból, jobbára azonban az „Introductio ad principia philosophiae solidioris” címü híres fömüvéből. Ebből is inkább következtetni tudunk. A természettudományos ismeretei szempontjából számára mérvadók voltak Huyghens, Newton, Leibniz, Wolff, Boerhaave, 's Gravesande, Musschenbroek, Johann és Daniel Bernoulli, Maupertuis, Clairaut és Euler. ${ }^{20}$ Ezek a nevek egyben minősítik is Hatvanit, hiszen kitűnik, hogy a legjeleseb-

${ }^{16}$ Vö. GAÁL, „A természettudományok oktatása és müvelése... ”, 77-148. Itt látszik, hogy szinte valamennyi tantárgy, illetve tudományterület, tudományág művelésében és oktatásában Hatvani István jelentős szerepet játszott.

${ }_{17}$ Műveiben hallatlanul sok külföldi tudósra hivatkozik, mint mérvadó személyiségekre.

18 Vö. Rácz István, szerk. Debrecen története, 2. kötet: 1693-1849, (Debrecen, 1981), 398.

19 Mivel Hatvani Eulerre és a Bernoulliakra nagyon figyelt, e sorok írója feltételezi, hogy valóban ismerte a differenciál- és integrálszámítást, és ezt a tehetségesebb tanítványainak taníthatta is szükebb körben.

${ }^{20}$ Ezek a nevek és még megannyi korabeli mérvadó tudósé igen gyakran olvashatóak Hatvani föművében: Introductio ad principia philosophiae solidoris, conscripta a Stephano Hatvani. Debrecen, Kállai 
bekre figyelt. Őket matematikusnak és filozófusnak nevezi, ${ }^{21}$ mert a fizikus szó az orvosok számára volt fenntartva/lefoglalva abban a korban. Kitűnik az is, hogy jól ismerhette Euklidész jelentőségét. ${ }^{22}$ Ami a tantárgyakat illeti, tanított teológiát, filozófiát, ontologiát, kozmológiát, matematikát, kísérleti fizikát. Ez utóbbi magában foglalta a kémiát, botanikát, orvosi "fiziológiát" (Hatvani szóhasználata), földrajzot, hidrosztatikát, mechanikát, asztronómiát és az elektromosság addigi eredményeit. ${ }^{23} \mathrm{~A}$ hazai tudományos életben különös megbecsülés övezte. ${ }^{24}$ Tudását itthon csodálták, személyét mérhetetlen tisztelettel vették körül. Emlékét a tanítványai szívük mélyen őrizték és adták tovább a következő nemzedékeknek. Majdnem száz évvel később Arany János és Jókai Mór is ezt a láthatatlan szellemi hatást érezte és örökítette meg. Aranynak bizonnyal hihetünk, mert az igazi professzort akarta soraival bemutatni: „S mi a természet zára, nyitja? Isten-dicsöségül tanitja. "25 - Itt egy érdekes dologra figyelhetünk fel. Ugyanis Arany János a Kollégiumban nem Péczely József irodalmár szorosabb köréhez tartozott, hanem leginkább vonzódott az „agg Simeon” tanárához, ez pedig Sárvári Pál volt, a kor egyik legnagyobb enciklopédikus műveltségü tudósa. Ebben pedig az az érdekes és különös, hogy Sárvárit még tanította Hatvani István, így Arany közvetlenül tőle is hallhatta a „magyar Faust” briliáns tanári egyéniségéről szóló történeteket.

\section{Orvosi müködése}

A mi Hatvanink Baselben Zwinger és König doktorok mellett képezte magát, de a matematikai és orvosi tudásukról híres Johann és Daniel Bernoulli tanítványa is volt. Ez utóbbiak meghatározóbbak lettek fejlődésére. Levelezett is velük. Ami az itthoni orvostudományi jelentőségét illeti, országos hírűvé részben a nagyváradi gyógyfürdők kedvező hatásának vizsgálata, másrészt pedig az ún. diákkórház létesítése révén vált. De ide sorolandó még Debrecen város és Bihar-vármegye gyógyszertári felügyelete is. Hatalmas elméje szinte mindent magába fogadott és tudását osztogatta bőkezűen: tanított, kutatott, gyógyított, szervezett, prédikált és mindeközben jelentős műveket írt. Valamennyi írása elejére odaírta az Alfa és Ómega betűket, jelezvén mély Krisztus-

György szedése, 1757. Magyar fordítás Tóтн Péter, Bevezetés a szilárdabb filozófia alapelveibe (Budapest: Debreceni Akadémiai Bizottság, Debrecen Városi Tanács és a Debreceni Református Kollégium, 1990).

${ }^{21}$ Vö. Hatvani, Introductio..., 21-22.

22 Vö. Hatvani, Introductio..., Praefatio, X. Szabó Árpád nyomán Euklídész nevét nem Eukleidész formában használjuk, mert a szócsalád nem követte a görögös írásmódot. Pl. euklideszi geometria.

${ }^{23}$ A felsorolt tantárgyak részletesebb ismertetését lásd Debrecen története, 2. kötet: 1693-1849, 398.

${ }^{24}$ Vö. KosÁry Domokos, Müvelödés a XVIII. századi Magyarországon, (Budapest: Akadémiai Kiadó, 1983), 565-566.

${ }^{25}$ Arany János, Hatvani. A vers két utolsó sorát idéztük. Feltételezhetjük, hogy ez a vers Sárvári Pál, az „agg Simeon” visszaemlékezései alapján született, ugyanis Hatvani még tanította Sárvárit, aki izgalmasan mesélhette el a „Hatvani-jelenséget”. 
hitét. Ugyanezt a két betűt láthatjuk 198 fennmaradt receptjén is, amelyeket diákoknak írt fel 1777 és 1785 között. Ezeket a diákköztársaság nevében maga a szenior fizette ki. Láthatók rajtuk a hatóanyagok latinul írva, valamint a kívánt mennyiségek, a gyógyszerészi elkészítés módja, a használati utasítás, néha a beteg neve, majd pedig dátumozás után Hatvani kézjegye. Ezeket a recepteket Csikesz Sándor találta meg az 1930-as évek végén a korabeli szenior elszámolási naplójában. Csupán ebből a 198 véletlenül fennmaradt rendelvényből számos betegséget, és mintegy kétszáz korabeli gyógyszernevet állapított meg Magyari Kossa Gyula orvosprofesszor és Diósdi Elekes György orvos. ${ }^{26}$ Mai szemünkkel nézve sok az ismerős név, pl. kerti angyalfü, rózsabefőtt, féregüző, növényi tejnedv, de derüt is fakaszthat bennünk néhány név, mint pl. étvágyjavító nyalat, kutyaháj, szárított ökörganéj, vagy ördögszar. Néhány receptet Csokonai József sebész, a költő édesapja írt, néhányról pedig nem tudjuk, kitől származik.

\section{A teológiai tudás is minösit}

Hatvani két tanártársa is püspöki tisztséget vállalt, ${ }^{27} \mathrm{~s}$ egyikőjük sem érzékelte, hogy a professzorság nem valamilyen mellékes foglalatosság, hanem teljes életet kíván. Ezt az elkötelezettséget, mint hívatást Hatvani jól látta. Ilyen körülmények között nem csoda, ha a 18. század második felében nem a teológusoktól, hanem magától a természettudós Hatvanitól jelent meg igazi dogmatikai mű, mégpedig az úrvacsoráról. Ezt az egyszerű címet adta neki: „Az úri szent vatsorára meg tanitó könyvetske." ${ }^{28}$ Csak az 1760-ban Baselben megjelent változata maradt fenn, melynek címlapján ez olvasható a fócím alatt folytatásként:

„[...] irattatott a’ gyengébbek kedvéért, hogy az Igaz Tudományt az Leányok, és Aszszonyok is könnyen és világossann meg foghassák; magok pedig a’ Szülék az ö gyermekeiknek; a’ tanitók, Preceptorok az ö Tanitványiknak; a’ gyengébb Lelki Pásztorok az ö Halgatóiknak a’ Szent Vatsorárúl valo Tudományt értelmessen 's meg fogható módonn elöl adhassák: ezen kívül hogy az Hitben gyengélkedők, az igaz Tudományban meg erösittessenek; az el tévelyedéstöl öriztessenek: kiki pedig a' Szent Vatsorával idvességessen élhessen."29

A nagy természettudós még ezt is odaíratta a címlapra: "A' Jésus Kristusnak egy Rendes Egyházi Szolgája által." E mü bevezető magyarázatának 15. oldalán azt olvassuk Hatvanitól, hogy az MDCCLV. évben írt már egy könyvecskét az úrvacsoráról

${ }^{26}$ Vö. Diósdi Elekes György, „Professzor Hatvani receptjei a debreceni diákok részére 1780 körül”. Theologiai Szemle, 15, 4. sz. (1940): 239-242.

${ }^{27}$ Szilágyi Sámuelről és Szatmári Paksi Istvánról van szó.

${ }^{28}$ Hatvani István, $A z$ úri szent vatsorára meg tanitó könyvetske, (Basel: Im-Hof, MDCCLX).

${ }^{29}$ Hatvani, $A z$ úri szent vatsorára..., a címlap szövege. 
„a' Tudósabbak kedvéert” ilyen címen: „De perpetuitate Fidei Ecclesiae Reformatae in Doctrina Sacrae Eucharistiae. "Ebből a könyvből nem maradt fenn egy példány sem. Ha előkerül, akkor még többet megtudhatunk Hatvani István teológiai felkészültségéről. Az említett, 1760-ban írt "mérsékelt szintu”" könyv is egy igen jó színvonalon megírt rendszeres teológiai mű. Aki ugyanis az úrvacsora teológiai értelmezésére vállalkozik, annak a teológiai felfogása, szemlélete, tudása is sokra becsülendő.

\section{Az Alfától az Ómegáig}

Hatvani István nagyszerủ egyéniségét dicséri az is, hogy sokszor prédikált, tanított a gyülekezetekben, diákkórházat hozott létre a Kollégiumban és szervezte a gyógyszerellátást a Debrecen környéki vármegyében. ${ }^{30}$ Házasélete is mintaszerű volt. Debrecenbe érkezése évében eljegyezte és feleségül vette a 17 éves Csatári Máriát, a város egyik szenátorának leányát. Tíz gyermekük született. ${ }^{31} \mathrm{~A}$ nagy természettudós igazi keresztyén életforma szerint meg is élte, amit hitt. Élete a szó szoros értelmében vett puritán létforma legszebb példája! 1786-ban hunyt el Debrecenben. A Kollégium a latin nyelvü sírkövét méltán helyezte el emlékezetül az Oratorium előterében. A sírkő az ALFA és OMEGA görög betűkkel kezdődik, amely betűket Hatvani István minden műve elejére odaírt. Amint láttuk, még az orvosi receptjeire felírta. Ez a jelkép kifejezi az ő egész életművét, az istenfélő természettudós örök üzenetét, amelyet Jézusról olvashatunk a Bibliában: "Én vagyok az Alfa és az Omega, ezt mondja az Úr, az Isten, aki van, aki volt, és aki eljövendó, a Mindenható!" (Jel 1,8)

${ }^{30}$ Hatvani István életrajzát már többen megírták, nagyon sokan részleteket dolgoztak fel életművéből, és számos diplomamunka, szakdolgozat született e témában. Sok-sok részletre itt nem térünk ki.

31 A tíz gyermekből három csecsemő korában, másik három pedig gyermekkorban vagy fiatalon halt meg, csak négy gyermekük érte meg a felnőttkort: Mária, Julianna, Pál és István. 